\title{
A Genetic Linkage Study of a Family With Norrie's Disease
}

\author{
L. ESAKOWITZ, ${ }^{*}$ C. CLARK, $\dagger$ N. HAITES,$\dagger$ K. KELLY $\dagger$ and A. W. JOHNSTON $\dagger$
}

Aberdeen

\begin{abstract}
Summary
A family having one member with Norrie's disease, $\mathrm{X}$-linked retinal dysplasia associated with hearing loss and mental retardation, was studied using DNA markers. The DNA markers were used to try and confirm the diagnosis of Norrie's disease by detecting a deletion of the $X$ chromosome. Linkage analysis using the polymorphic DNA markers was performed and this allowed more accurate determination of the carrier status of two sisters of the affected boy than by empiric risk calculation. The advantage of multiple polymorphic DNA markers for linkage analysis is illustrated.
\end{abstract}

Norrie's disease (McKusick No 31060¹), or progressive oculo-acoustic-cerebral dysplasia is a rare, $\mathrm{X}$-linked recessive disorder. It is characterised by bilateral blindness, present from birth or in infancy and often associated with mental retardation and neuro-sensory deafness. ${ }^{2,3}$ There are no clinical stigmata of Norrie's disease (ND) in carrier females and the risk of being a carrier of ND has had to be determined on the basis of empiric data. Linkage studies using DNA markers have provided an indirect method of detecting the presence of disease gene loci. ${ }^{4}$ The DNA probe L1.28 has been found to map on the short arm of the $\mathrm{X}$ chromosome in the Xp11 region, with close genetic linkage to ND. ${ }^{5}$ This has been used for linkage studies to determine which female family members are carriers of ND. . $, 6,7^{-}$

Information obtained using DNA markers in families with inherited conditions is useful predictively if it distinguishes between family members. Two criteria must be fulfilled for DNA markers to be informative for a family. Key family members must be heterozygous for the marker used, i.e., the DNA probe should reveal at least two different size DNA fragments in affected parents or obligate carriers of the inherited abnormality. The second criterion is the phase of the DNA polymorphism, i.e., the information gained about a family should reveal which DNA fragment size segregates with the inherited condition in the family. Where the information gained from DNA markers does not fulfill these criteria, it cannot be used for genetic linkage studies, and the family is said to be non-informative for that DNA probe.

If the most closely linked probe is noninformative, less tightly linked probes can be used and the closeness of linkage taken into account when calculating genetic risks for the family. About $45 \%$ of the general population is heterozygous for the probe L1.28, and it will therefore be non-informative for linkage studies in many cases. ${ }^{8}$ The use of further probes which map close to L1.28 may help under these circumstances.

DNA markers may also be used to detect subtle chromosomal deletions and the probe 
L1.28 was used to identify a deletion in the Xp11 region in affected members of a family with Norrie's disease. ${ }^{6}$

We report a family with ND, investigated for chromosome deletions and carrier female status using multiple DNA probes.

\section{Case Report}

S.W. (III ${ }_{3}$, Fig 1b) was referred to the eye clinic at age 5 weeks. He was born at term to a 30 year old $P_{2} G_{3}$, well mother and an unrelated 30 year old well father. There was no family history of ocular or other anomalies.

He was found to have a poor response to light. Bilateral microphthalmos was present with horizontal corneal diameters of $7 \mathrm{~mm}$ right and left. Both irides were atrophic with shallow anterior chambers and dense cataracts were present. Ultrasound demonstrated retrolental masses bilaterally (Fig 2). No other anomalies were present and he was assessed as being developmentally appropriate for age. Brain-stem evoked responses showed prolonged latency, and a computed tomography (CT) scan showed multiple $2 \mathrm{~mm}$ paraventricular gliotic and calcified lesions. Serological tests for congenital infection were negative and screening tests for metabolic disorders did not reveal any abnormalities. The karyotype of all family members was normal.

A diagnosis of ND was made on the basis of the eye findings in a male infant, but with no other affected family members, autosomal recessive retinal dysplasia cannot be excluded. ${ }^{2,9}$ The family was referred for genetic counselling and DNA studies were done to try and detect a deletion in the Xp11 region and to determine the carrier status of the female family members.

\section{Methods}

DNA was extracted from venous blood leukocytes, ${ }^{10}$ digested with restriction endonucleases and subject to electrophoresis on $1 \%$ agarose gels. The DNA fragments were transferred to nylon membranes by Southern blotting ${ }^{11}$ and hybridised to probes labelled to a high specific activity by hexadeoxynucleotide priming. ${ }^{12}$ The probes used were: 754 (PstI polymorphism), L1.28 (TaqI polymorphism), OTC and 58.1 (both MspI polymorphisms). ${ }^{13}$ The nylon membranes were prehybridised and hybridised according to the manufacturer's instructions,${ }^{14}$ and calculation of risk information was done using the computer program RISKDNA. ${ }^{15}$

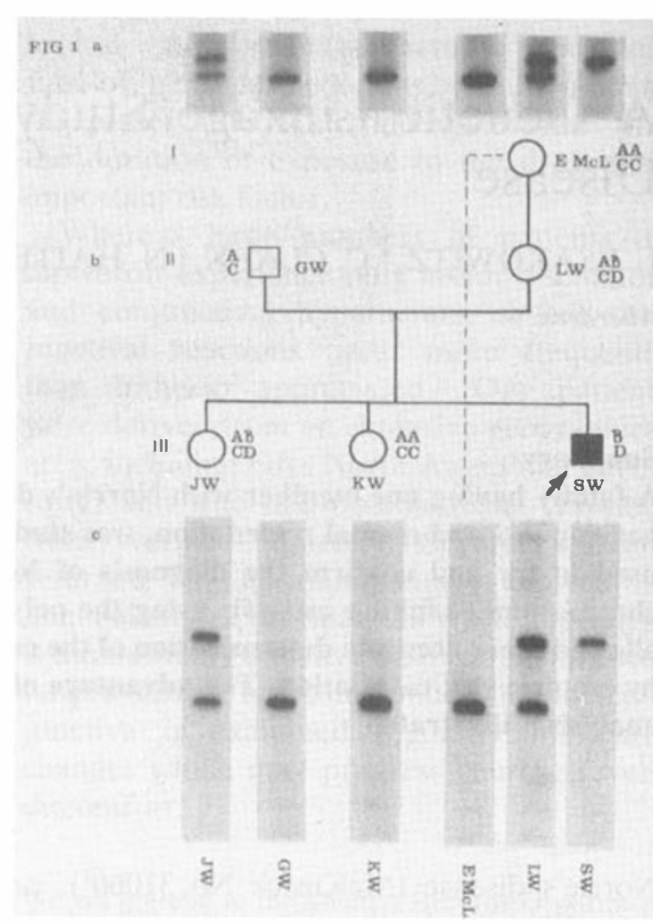

Fig. 1a. Autoradiograph showing the bands detected using the DNA probe 75.4 .

1b. Pedigree of the reported family indicating the $D N A$ fragment polymorphisms as $A, B$, and $C, D$. Note the pattern in $S W$ as $B D$ which is also present in his mother and one sister (JW), but not in his father or other sister $(K W)$.

1c. Autoradiograph showing the bands detected using the DNA probe 58.1.

\section{Results}

DNA probe L1.28 was used initially, and detected the same single DNA band in all family members. It was thus not helpful for detecting a deletion, nor informative for linkage studies. Similarly, OTC only detected one DNA fragment size. The two informative probes, 75.4 and 58.1 detected two different DNA fragment sizes (Fig 1a, 1c) allowing linkage calculations to be performed.

Empiric data ${ }^{16}$ indicate that the risk of $\mathrm{II}_{2}$ (S.W.'s mother) being a carrier is $66.6 \%$. Her daughters will have half this risk, ie $33.3 \%$ (only inheriting one of mother's X chromosomes). The calculated risk of sister III $_{1}$ being a carrier was $59 \%$ and for sister III $_{2}$ was $8 \%$ using the information gained from the DNA probes. 


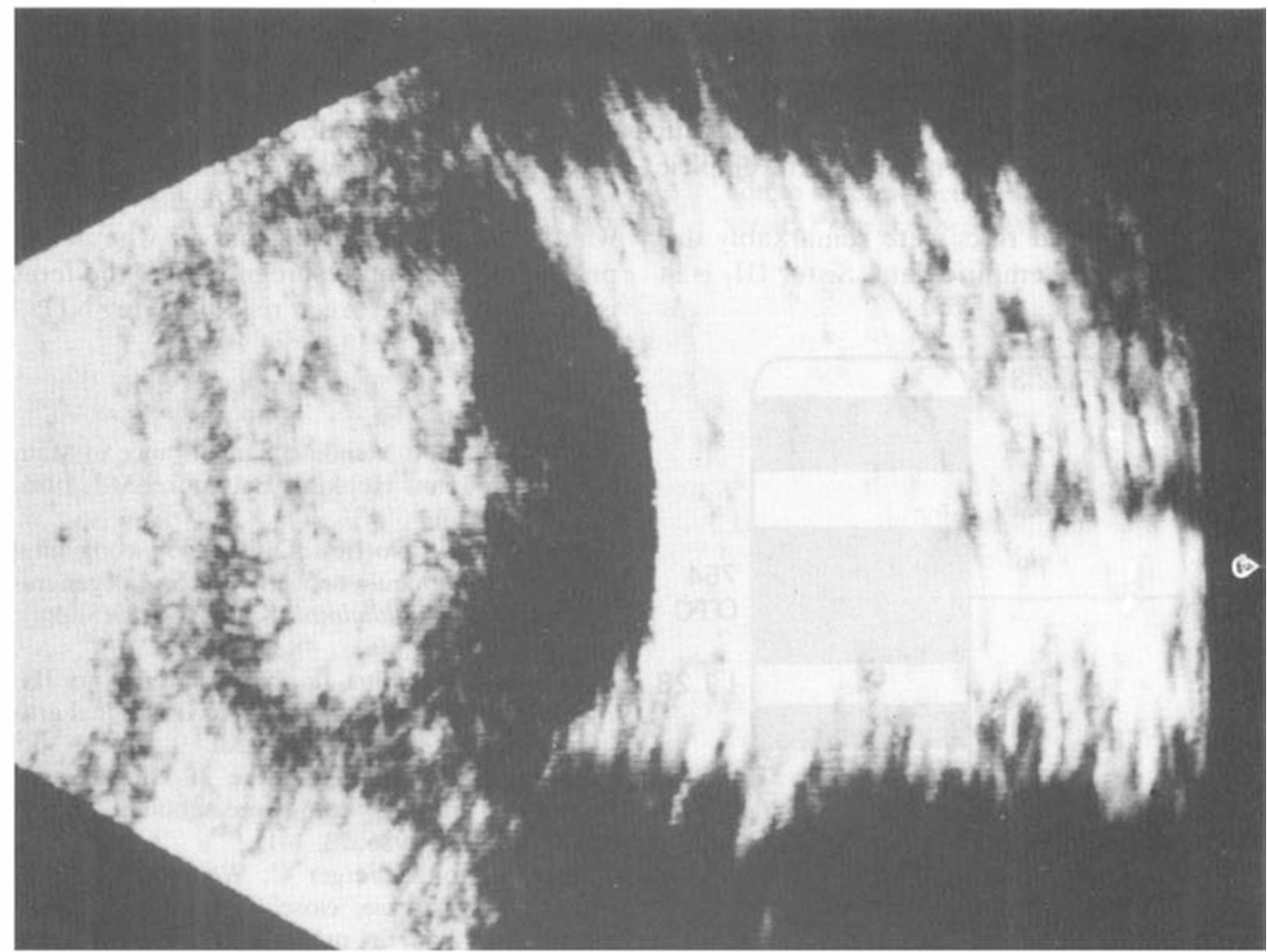

Fig. 2. Ultrasound of the right eye of SW showing the retrolental mass.

\section{Discussion}

ND must be considered in male infants with bilateral retrolental masses. ${ }^{2}$ Retinal dysplasia complicated by degeneration and complicated by cataracts, iris atrophy, shallow anterior chambers are typical of ND as in $\mathrm{III}_{3}$. Microphthalmia has been reported and phthisis bulbi may be the end stage of the disease. Mental subnormality and sensory neural deafness have been present in about a third of cases. ${ }^{3}$ The differential diagnoses includes recessively inherited retinal dysplasia, ${ }^{9}$ familial exudative vitreoretinopathy, retinoblastoma and retinopathy of prematurity if bilateral, and toxoplasmosis, Coats' disease, retinal hamartomas and persistent hyperplastic primary vitreous if unilateral. ${ }^{2}$ The paraventricular site and the size of the calcified cerebral lesions resemble those described in tuberose sclerosis. No other account of CT scans in Norrie's disease appears to have been recorded previously.
Genetic linkage studies indirectly assess for the presence of a disease gene locus and can be used even if the precise locus for that disease is unknown, ${ }^{4}$ as in ND. The different size DNA fragments produced by digestion with restriction endonucleases (restriction fragment length polymorphisms, RFLP's) and detected by DNA probes have provided many DNA markers for use in linkage studies. ${ }^{4,15}$ These markers will only be informative where the family is heterozygous for that particular marker, ie two different DNA fragment sizes are detected by a particular DNA probe in some family members.

The probe L1.28, which maps at the DSX7 locus, and is most closely linked to ND was not informative as only one DNA fragment size was detected in all family members. This prompted the use of further DNA probes which map in the same region as L1.28. The probe OTC was similarly non-informative, but probes 75.4 and 58.1 revealed DNA polymorphisms (RFLP's) which were used in 
the risk calcualtions. These two probes do not map as close to the ND locus as does L1.28, but the information gained still allowed calculation of carrier risk status with improved precision, compared with empiric data.

The calculated risks were remarkably different from the empiric data. Sister III $_{1}$ is at

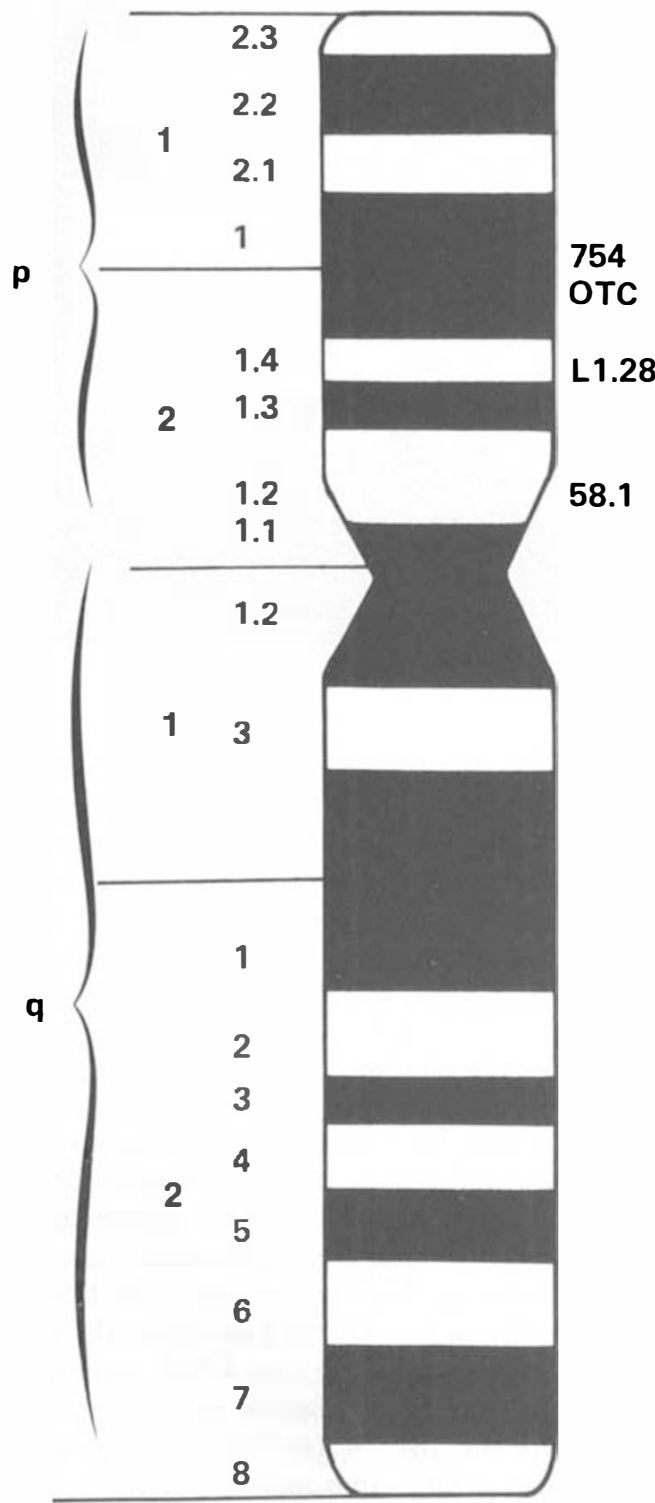

Fig. 3. Schematic diagram of the $X$ chromosome indicating the loci mapped by the DNA probes used in this study. much greater risk of being a carrier of ND $(59 \%)$ than the empiric data would indicate $(33 \%)$, and sister $\mathrm{III}_{2}$ at a much reduced risk of $8 \%$. Such information may be of considerable value to these patients, allowing them to make a more informed decision about whether to become pregnant, or whether to proceed with a future pregnancy, if the fetus is male, and therefore at risk of having ND.

\section{References}

${ }^{1}$ McKusick VA: Mendelian Inheritance in Man, 7th ed, Johns Hopkins, Baltimore, Md, 1986, 1435-1436.

2 Warburg M: Norrie's Disease. A congenital progressive oculo-acoustic-cerebral degeneration. Acta Ophthalmol (Kbh) 1966, 89(Suppl): 1-147.

3 Johnson SS, Hanna JE, Nevin NC Bryars JH: Norrie's Disease. Birth Defects: Original article series 1982, 18(6): 729-38.

${ }^{4}$ Cooper DN and Schmidtke J: Diagnosis of genetic disease using recombinant DNA. Hum Genet 1986, 73: 1-11.

${ }^{5}$ Gal A, Stoltzenberger C, Weinker T, et al.: Norrie's Disease: close linkage with genetic markers from the proximal short arm of the $\mathrm{X}$ chromosome. Clin Genet 1985, 27: 282-3.

${ }^{6}$ De la Chapelle A, Sankilla EM, Lindlof M, et al.: Norrie's Disease caused by a gene deletion allowing carrier detection and prenatal diagnosis. Clin Genet 1985, 28: 317-20.

${ }^{7}$ Polomeno RC, Zeesman, MacDonald IA, et al.: Norrie's disease in a French Canadian kindred: attempt to detect carriers by DNA analysis. Can J Ophthalmol 1987, 22: 21-3.

${ }^{8}$ Bakker E, Goor N, Wrogemann K, Kunkel LM, et al.: Prenatal diagnosis and carrier detection of Duchene Muscular Dystrophy with closely linked RFLP's. Lancet 1985, 1: 655-8.

${ }^{9}$ Ohba N and Yamashita T: Primary vitreo-retinal dysplasia resembling Norries Disease in a female: association with $\mathrm{X}$ autosome chromosome translocation. Br J Ophthalmol 1986, 70: 64-71.

${ }^{10}$ Kunkel LM, Smith KD, Boyer SH, Borgaonkar DS, et al.: Analysis of human Y chromosomespecific reiterated DNA in chromosome variants. Proc Nat Acad Sci USA 1977, 74: 12459.

"Southern E: Gel electrophoresis of restriction fragments. Methods Enzymol 1979, 68: 15276.

12 Feinberg AP and Vogelstein B: A technique for 
radiolabelling DNA to a high specific activity. Anal Biochem 1984, 137: 266-7.

${ }^{13}$ Davies KE: Molecular genetics of the human X chromosome J Med Genet 1985, 22: 243-9.

${ }^{14}$ Hybridization protocol. Nen Research Products, Boston, USA. DuPont 1985.

${ }^{15}$ Sarfarazi $\mathbf{M}$ and Williams $\mathrm{H}$ : A computer prog- ram for estimation of genetic risk in X-linked disorders, combining pedigree and DNA probe data with other conditional information. J Med Genet 1986, 23: 40-5.

${ }^{16}$ Fraser Roberts JA, Pembery MA: An Introduction to Medical Genetics, 8th ed. Oxford University Press, Oxford, 1985. 341-2. 